\title{
Taxonomic and nomenclatural notes on Pontic-Mediterranean coastal and some Australasian taxa of Salsola (Chenopodiaceae)
}

\author{
Sergei L. MOSYAKIN \\ M.G. Kholodny Institute of Botany, National Academy of Sciences of Ukraine \\ 2, Tereshchenkivska Str., Kyiv (Kiev) 01004, Ukraine \\ s_mosyakin@hotmail.com
}

Mosyakin S.L. Taxonomic and nomenclatural notes on Pontic-Mediterranean coastal and some Australasian taxa of Salsola (Chenopodiaceae). Ukr. Bot. J., 2017, 74(6): 521-531.

Abstract. Current and historical views on taxonomy and nomenclature of Pontic-Mediterranean coastal and some Australasian taxa of Salsola (Chenopodiaceae) are analyzed. Taxonomic identity and nomenclature of several names applied and misapplied to members of the species group known in recent publications mainly as Salsola pontica (Pall.) Degen sensu lato are discussed. It is demonstrated that Kali dodecanesicum C. Brullo \& al. is a later synonym of Salsola squarrosa Steven ex Moq., which appears to be the earliest species-rank name available for the whole Pontic-Mediterranean group of taxa. This group is represented by Western Mediterranean ( $S$. controversa Tod. ex Lojac.), Eastern Mediterranean ( $S$. squarrosa s. str.), and mainly Pontic ( $S$. pontica s. str.) geographical races. Considering the blurred morphological and geographical limits between these taxa, they are better treated as three subspecies of $S$. squarrosa: subsp. controversa (Tod. ex Lojac.) Mosyakin, comb. nov., subsp. squarrosa, and subsp. pontica (Pall.) Mosyakin, comb. nov., respectively. It is demonstrated that S. macrophylla R. Br. (described from Australia) is not conspecific with any of Pontic-Mediterranean coastal taxa but is probably related to the currently recognized species $S$. australis R. Br. The identity of $S$. brachypteris Moq. (described from Java, Indonesia) remains uncertain but, judging from available evidence, it is most probably either related to or conspecific with $S$. macrophylla, or some other insufficiently known Australasian species. The problem of conflicting typifications and application of the name $S$. caroliniana Walter is briefly discussed; it is concluded that the name should be proposed for rejection. The need for further morphological, molecular phylogenetic, and phylogeographic studies of coastal Eurasian and Australasian species of Salsola is emphasized.

Keywords: Salsola, Chenopodiaceae, Salsoloideae, nomenclature, taxonomy, biogeography

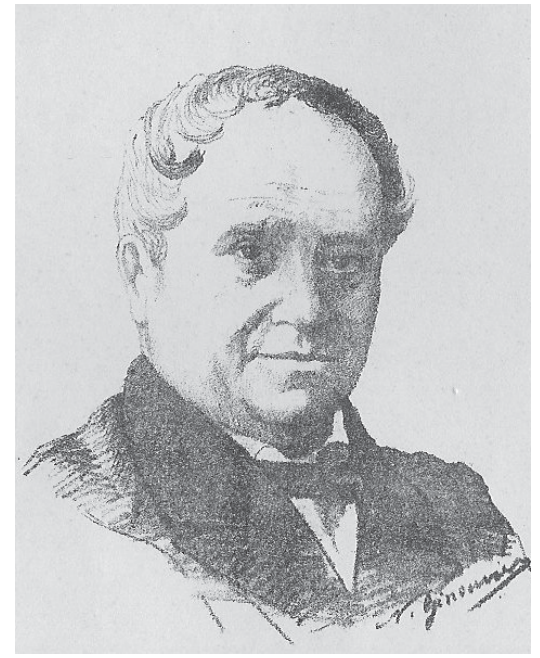

This article is dedicated to Alfred [Christian Horace Bénédict Alfred] Moquin-Tandon (1804-1863), whose excellent publications on Chenopodiaceae remain valuable resources for all plant taxonomists studying this fascinating plant family [image in Public Domain: https://fr.wikipedia.org/wiki/Alfred_ Moquin-Tandon\#/media/File:Alfred_Moquin-Tandon.jpg]

\section{(C) S.L. MOSYAKIN, 2017}

\section{Introduction}

Salsola L. sensu lato (Chenopodiaceae: Salsoloideae: Salsoleae) is a notoriously complicated group from the taxonomic and phylogenetic viewpoints; it was recently split into numerous segregate genera supported by molecular phylogenetic and partly morphological and biogeographical evidence (see Akhani et al., 2007; Wen et al., 2010; Wen, Zhang, 2011, Voznesenskaya et al., 2013; Schüssler et al., 2017, and references therein). The process of generic rearrangements in that group is still far from being complete, and further taxonomic and nomenclatural changes are expected. Recent nomenclatural and taxonomic developments resulting from molecular phylogenetic studies and nomenclatural controversies (Akhani et al., 2014; Mosyakin et al., 2014) were summarized in several recent publications (e. g., Hernández-Ledesma et al., 2015; Mosyakin et al., 2017; Mosyakin, 2017, and references therein) and will not be repeated here.

I provide here a brief outline of the state of current knowledge of and remaining taxonomic and nomenclatural problems in just one the group of coastal taxa presumably native to the Mediterranean region and extending to the maritime areas of the Black and Caspian seas and the Sea of Azov. Several names 
were applied and misapplied to these coastal plants, and some additional taxa were recently described or recognized. Morphologically similar plants, however, also occur in Australasia (where some might be aliens and some native plants: see Borger et al., 2008; Hrusa, Gaskin, 2008; Chinnock, 2010), North America (all aliens; see Mosyakin, 1996, 2003; Rilke, 1999; Hrusa, Gaskin, 2008; Ayres et al., 2009), and probably some other coastal regions of the world.

In her concise monograph of Salsola sect. Salsola sensu lato, Rilke (1999) recognized just two western European and Mediterranean coastal taxa of Salsola: S. kali L. sensu stricto (from the Atlantic and Baltic coasts) and S. tragus L. subsp. pontica (Pall.) Rilke (from shores of the Mediterranean, Black and Caspian seas, and the Sea of Azov). She also provided extensive lists of synonyms for each recognized taxon, in most cases with information on their types, and relevant nomenclatural references. The species included by Rilke (1999) in her "Salsola sect. Salsola sensu lato" (in fact, she recognized sect. Salsola sensu stricto, sect. Sogdiana Rilke, sect. Androssowia Rilke, and sect. Kali Dumort. with three subsections) are now placed in three genera: Salsola sensu stricto, Soda (Dumort.) Fourr. (Fourreau, 1869; see Mosyakin et al., 2017), and Turania Akhani \& Roalson (Akhani et al., 2007). Additionally, one species (S. rosacea L.) probably fits in Noaea Moq. (see Akhani et al., 2014); as far as I am aware, no relevant combination has been validated yet.

The present article grew from my recent paper published with a modest intention to communicate a new record of the alien species $S$. paulsenii Litv. in Ukraine (Mosyakin, 2017). That article, despite being rather limited in its scope, contained a brief overview of species of Salsola sensu lato (now placed in Salsola sensu stricto, Caroxylon Thunb., Climacoptera Botsch., Pyankovia Akhani \& Roalson, and Soda) occurring in Ukraine, and some notes on nomenclature and taxonomy of coastal Salsola pontica and related taxa.

Taxa placed by Rilke (1999) in Salsola tragus subsp. pontica: a brief overview

I already commented that "[s]ynonymization of the Australian taxon S. macrophylla with the Pontic (and eastern Mediterranean?) S. pontica (Pall.) Degen (= Kali ponticum (Pall.) Sukhor., S. tragus subsp. pontica (Pall.) Rilke) cursorily done by Rilke (1999) and later accepted by Galasso and Bartolucci (2014), who coined the combination Kali macrophyllum (R. Br.) Galasso \& Bartolucci, seems to be at least questionable. Their identity has not been proven yet beyond doubt, and until such a proof is available, I prefer to use the name S. pontica for our plants" (Mosyakin, 2017: 410). I also concluded that for establishing the priority name (or names) for the Pontic-Mediterranean coastal species (or a group of species) "the identity of two earlier species-rank names ( $S$. macrophylla described from Australia and S. brachypteris Moq. described from Java, Indonesia) mentioned by Rilke (1999) in synonymy of her $S$. tragus subsp. pontica should be critically assessed as well" (Mosyakin, 2017: 410).

Following these preliminary conclusions, in this article I provide further results of my critical assessment of available evidence on the possible identity and application of the names $S$. macrophylla and $S$. brachypteris and on forgotten (and almost never taxonomically recognized until now) Mediterranean taxa $S$. squarrosa Steven ex Moq. and $S$. controversa Tod. ex Lojac. Additionally, it was necessary to re-evaluate available data on the name $S$. caroliniana Walter, a very obscure taxon described from North America in 1788. Two new nomenclatural combinations are proposed for Pontic-Mediterranean coastal taxa.

Herbarium acronyms are given following Thiers (2017-onward). Digital images of many herbarium specimens cited in the article are available online.

\section{What is Salsola macrophylla $\mathrm{R}$. Br.?}

The type specimen of Salsola macrophylla (BM000016766, available at https://plants.jstor. org/stable/10.5555/al.ap.specimen.bm000016766) has the printed label on blue paper ("R. Brown, Iter Australiense, 1802-5. [Presented by direction of J.J. Bennett, 1876], No. 3082" [handwritten number added - S.M.]) and the handwritten label ("2. Salsola macrophylla. prodr. 411. East Coast") attached to it. There is also a handwritten pencil text in the lower right corner of the sheet: "Brown's manuscript description of Salsola macrophylla was based on material collected on inner entrance [of] Thirsty Sound, Queensland [illegible text follows, scan cut - S.M.]". A recent map with a cross indicating the locus classicus and Rilke's identification label ("Salsola tragus L. subsp. pontica. Det./rev. S. Rilke. Kassel, 30.1.1999") are also attached. In my opinion, the specimen does not belong to $S$. pontica (sensu stricto or sensu lato).

The type specimen contains four plant fragments: two larger terminal branches (mounted on the left and right sides of the sheet), a middle portion of a branch (central lower part of the sheet), and a small terminal part of a branch (center of the sheet). All fragments are morphologically similar and thus there is no reason to suspect that they represent a mixed collection of different taxa. Larger branch fragments are rather thick; they belonged to a robust or probably even somewhat lignescent plant with erect or somewhat ascending 
branches. Stem leaves are indeed rather long; fruits are mainly immature, but it looks like the fruits in nodes and lower parts of branches have short-winged or almost wingless tepals. However, a few fruits in the terminal part of the central branch fragment are better developed, and those fruits evidently have tepals with quite well-developed and broad wings. One fruit is especially well visible; as far as it can be seen in the high-resolution digital image, its two minor wings are rather large also, similar to those in S. australis. Judging from that evidence, in combination with morphological data provided by Borger et al. (2008) and Chinnock (2010), we can conclude that $S$. macrophylla most probably represents a rather tall-growing tropical and subtropical Australasian race, probably a lignescent short-lived perennial, which is related to $S$. australis. Its taxonomic status remains obscure, but data of Borger et al. (2008) and Chinnock (2010) indicate that some taxonomic recognition of that plant is to be expected (a separate species, or a subspecies of $S$. australis?), following further research. Consequently, the name S. macrophylla should not be applied to any native Pontic-Mediterranean coastal taxa of Salsola.

\section{What is Salsola brachypteris Moq.?}

Rilke (1999: 133) listed the names Salsola brachypteris Moq. and S. kali var. brachypteris (Moq.) Benth. (Bentham, 1870) in synonymy of her $S$. tragus subsp. pontica (Pall.) Rilke. If it is indeed so, the name $S$. brachypteris could be of priority for the whole PonticMediterranean complex, or for some of its segregate species (if recognized). Because of that I studied in more detail the protologue, other relevant literature, and high-resolution images of original and some other specimens available online.

The name $S$. brachypteris appeared for the first time in the article by Moquin-Tandon (1835: 214) as nomen nudum because no description or diagnosis of the species was provided. The name was mentioned in the key to groups of species of Salsola and was included in the third group, with the following diagnosis: "Alæ crassiusculæ, brevissimæ (unguiformes). Ex.: S. Soda L., S. collina Pall. Ill., S. brachypteris Moq. in Belang." It is evident that this brief diagnostic statement was applied to several species, of which only three taxa were mentioned as examples. No diagnostic characters distinguishing $S$. brachypteris from other taxa have been provided. Consequently, the name remained invalid until 1840, when Moquin-Tandon (1840: 147) published the following description:

"28. S. BRAchypteris (Moq. in Belang. fl. Pers.) herbacea suberecta glauca ramosa, ramis alternis suberectis, foliis alternis elongatis semiteretibus spinoso-muricatis crassis carnosis rigidibus, floralibus vix dilatatis, bracteis folio florali multò brevioribus perigonio fructifero longioribus, floribus solitariis, alis minutissimis squamæformibus vix distinctis cartilagineis.

In insulà Java.

Planta sicca fragilis. Folia caduca. Facies S. Sodæ. Fructus vix inflati. (v. s. ex itin. Belang.)".

Later Moquin-Tandon (1849: 189) provided an updated description and additional information on his species, including references to additional herbarium specimens seen ("v. s. in h. Belang. Mus. paris. DC. et Hook.").

The plant was collected in Java (now Indonesia) by Charles Paulus Bélanger (1805-1881) during his travels in Europe, the Caucasus, Persia, India, Indonesia, and some other regions in 1825-1829, described in his Voyages aux Indes orientales par le nord de l'Europe, les provinces du Caucase, la Géorgie, l'Arménie et la Perse, suivi de détails topographiques et autres sur le Pégou, les îles de Java, de Maurice et de Bourbon, sur le Cap de Bonne-Espérance et Sainte-Hélène, pendant les années 1825, 1826, 1827, 1828 et 1829; see Ross (1964) for complicated bibliographic details. In 1828 Bélanger visited Java, mainly areas of Batavia (now Jakarta) and Buitenzorg (now Bogor), and some adjacent islands (Hooker, 1836).

In subsequent publications Salsola brachypteris was usually mentioned as a synonym of $S$. kali sensu latissimo (e. g., Boerlage 1900: 38; Backer, 1949: 106), and only rarely it was recognized as a species (e. g., Miquel, 1855: 1022; Hooker, 1859: xlvi).

I traced online the original specimen from Java that was certainly studied in detail by Moquin-Tandon and should be considered the type (P00799151; available online from https://science.mnhn.fr/institution/mnhn/ collection/p/item/p00799151). The sheet contains two plant fragments (one mounted in the center of the sheet, another much smaller fragment in the envelope in the upper right corner), the labels, and additional annotation slips on which Moquin-Tandon wrote a description (which was evidently used for preparing the published descriptions) and analytical drawings illustrating diagnostic characters of the species. The yellow-paper label in the lower left corner of the sheet contains the following text: "Salsola brachypteris Moq. Java Nº. 4. M. Bèlangé [Bélanger - S.M.]".

There are several other available specimens in $\mathrm{P}$ identified as S. brachypteris (e.g., P05196083, image available from https://science.mnhn.fr/institution/ mnhn/collection/p/item/p05196083;P00256012,https:// 
science.mnhn.fr/institution/mnhn/collection/p/item/ p00256012; P00256013, https://science.mnhn.fr/ institution/mnhn/collection/p/item/p00256013), but the two last cited specimens were collected in Timor, and they are morphologically different from the type specimen. The sheet P05196083 contains two gatherings, one from Timor [four fragments, left side of the sheet: "Herb. Mus. Paris. Salsola brachyptera Moq. (an differt ab australi Br.?) I-le Timor"] and one from Java (one broken branch, most probably a fragment of the type P00799151: "Herbarium Moquinianum. Salsola brachypteris Moq. Java (Belangé, no. 4) A. Moq.-Tand.", with a characteristic signature of Moquin-Tandon). Both specimens have small slips "Herb. Al. de Bunge" attached at larger labels. Most probably these plant fragments were provided to Bunge by Moquin-Tandon or some other colleague, and later returned to the $\mathrm{P}$ herbarium through the herbarium of E. Cosson (see the small label in the upper right corner of the sheet). All mentioned specimens from Timor evidently are members of Salsola sect. Salsola ("S. kali$S$. tragus - S. pontica - S. australis etc. aggregate" in the widest possible sense) and are morphologically different from the type from Java (P00799151, formally designated here as the lectotype of Salsola brachypteris Moq., because of the existence of the second specimen of Moquin-Tandon in P: P05196083, right-hand plant, possibly a fragment of the type).

After studying the high-resolution image of the type of $S$. brachypteris, I am certain that there is not even a slight possibility that this name is applicable to any native Pontic-Mediterranean taxon of the Salsola pontica group. First, judging from the available larger fragment of P00799151, the plant itself was probably either a robust annual or a short-lived perennial, somewhat lignescent at base. Leaves were probably easily detached at base, falling off (caducous) at maturity/senescence or under unfavorable environmental conditions (changes of draught and rainy seasons?), which was properly noted by Moquin-Tandon $(1840,1849)$ in the original and updated descriptions. Most importantly, the branches and bases of lower leaves in that fragment are condensed, positioned very close to each other, with leaves subopposite or even opposite (!). That leaf arrangement is very peculiar, almost never occurring in most species of Salsola sect. Salsola, and it explains why Moquin-Tandon (1835, 1840, 1849) so consistently compared his plant to Salsola soda L. (now Soda inermis Fourr.).

Thus, the characters observed in the plant fragments of the type specimen and data of the protologue and later publications indicate that $S$. brachypteris is definitely not conspecific with any native Pontic-
Mediterranean taxon (either sensu lato or sensu stricto). It might be related to $S$. macrophylla (see above), a predominantly tropical Australasian (or exclusively Australian?) race of the $S$. australis aggregate, which is in need of further research. It should be noted that some Australian specimens of Salsola also have that very peculiar branching habit, with subopposite or opposite arrangement of lower branches and leaves (see, for example, a specimen of "S. kali var. strobilifera Benth."; K000899590, image available from: https:// plants.jstor.org/stable/viewer/10.5555/al.ap.specimen. k000899590). Many intriguing questions about that taxon remain, but, in any case, we can safely exclude the name $S$. brachypteris from our further considerations on appropriate names to be applied to Pontic-Mediterranean taxa.

In my opinion, the amazing morphological diversity of Australian Salsola does not fit just one native species now recognized as $S$. australis. Judging from specimens and images I have seen, and from other available evidence (Mueller, 1891; Wilson, 1984; Rilke, 1999; Borger et al., 2008; Chinnock, 2010, etc.), there are at least five native Australian species of Salsola (plus probably one or two introduced ones?). An article is under preparation (Mosyakin et al., in progress), in collaboration with Australian colleagues.

\section{The problem of Salsola caroliniana Walter}

It is now evident that the names $S$. macrophylla and $S$. brachypteris should not be applied to native Pontic-Mediterranean taxa. However, before proposing taxonomic and nomenclatural solutions for the coastal Pontic-Mediterranean species complex of Salsola, we should consider in more detail another earlier name, $S$. caroliniana Walter, which may compete in terms of priority with the names of Pontic-Mediterranean taxa.

Salsola caroliniana was described by Thomas Walter in Flora Caroliniana (Walter, 1788: 111), one of the earliest North American floristic and taxonomic publications consistently applying binomial nomenclature and Linnaean taxonomy. The real identity of that species name remains uncertain (see Botschantzev, 1974; Tzvelev, 1993, 1996; Mosyakin, 1996, 2003; Rilke, 1999, and references therein). The standing type of S. caroliniana (Botschantzev, 1974: 614; Rilke, 1999) is a small fragment of a Salsola branch mounted on page 93 (specimen 93-F) of the Walter Herbarium folio volume kept at BM (image available from Botanica Caroliniana - Texts, Data, and Images at http://folio. furman.edu/botcarweb/indices?urn=urn:cite:fufolio img:BotCarWalter.walter_v_93_01135). It definitely belongs to the $S$. kali - S. tragus - S. pontica aggregate, but is hardly identifiable precisely as a concrete species or subspecies of that group. 
It was commonly assumed that specimens mounted in the Walter Herbarium folio are types and other original specimens used by Walter for descriptions of new taxa in his Flora Caroliniana, but that view was challenged by Ward (2006, 2007), who claimed that most specimens from the Walter Herbarium cannot be regarded holotypes and in most cases are not suitable for designation of lectotypes. He later proposed the "neotype" for S. caroliniana (Ward, 2008: 483), the specimen collected in South Carolina in 1939 (GH00247988, image available from https://plants. jstor.org/stable/10.5555/al.ap.specimen.gh00247988). That "neotypification" is, however, ineffective because the earlier typification has been disregarded (Art. 9.19 of ICN: McNeill et al., 2012); it is also evidently in conflict with the protologue (Art. 9.19(b) of ICN: McNeill et al., 2012). The name $S$. caroliniana is not in current use, and was used rather inconsistently in the past. Considering these and some other arguments, especially the history of misapplication of the name, its uncertain taxonomic identity, and conflicting typifications, I believe that the best solution is to reject the name $S$. caroliniana. The relevant nomenclatural proposal has been prepared (Mosyakin, manuscript submitted to Taxon); it contains more arguments and detailed information on the nomenclatural problem of S. caroliniana.

\section{What is Kali dodecanesicum C. Brullo \& al.?}

Brullo et al. (2015b) described from the Dodecanese archipelago (Greece; holotype from Rhodes) a new species, Kali dodecanesicum, and proposed to distinguish their new taxon and Kali ponticum (Salsola pontica) using the following characters mentioned in the key (Brullo et al., 1.c.: 67):

Kali dodecanesicum: Plant yellowish-green, prostrate, with branches prostrate-ascending, perianth 2.5$3.0 \mathrm{~mm}$ long, anthers $2 \mathrm{~mm}$ long, fruiting perianth 4.0-4.5 in diameter with wings $0.5-1.0 \mathrm{~mm}$ wide.

Kali ponticum: Plant green to green-glaucous (often tinged with reddish), erect with branches ascending, perianth $2.0-2.2 \mathrm{~mm}$ long, anthers $0.8-1.4 \mathrm{~mm}$ long, fruiting perianth $3.0-3.5$ in diameter with wings $0.2-$ $0.4 \mathrm{~mm}$ wide or with tubercles only (at least in Israel).

However, judging from my experience with living plants observed in southern Ukraine (shores of the Black Sea from Odessa Region to Crimea) and herbarium specimens consulted mainly in KW, LE, and in several other herbaria, plants of $S$. pontica from Ukraine are normally (or at least quite often) yellowish-green or light green; dark green individuals sometimes also occur, but they seem to be less common. Wings are usually short or barely developed, but this character is very variable and fruits with winged tepals (with wings up to $1 \mathrm{~mm}$ wide) sometimes occur in middle and upper parts of branches. Both erect and prostrate-ascending plants were observed in $S$. pontica, but the growth habit in this taxon greatly depends on environmental conditions. Besides, Pallas (1803: 37) mentioned in the protologue that his $S$. kali var. pontica is a prostrate plant (at least when young): "Planta annua patentissima, diffusa, ab imo ramosissima, junior prostrata..."

Brullo et al. (2015b: 67) also indicated that, in their understanding, K. ponticum has "stems and leaves green, glabrous or subglabrous..."; but Pallas (1803:37) reported that the whole plant is slightly hispid-pilose ("...tota planta subpiloso-aspera..."). Both glabrous (common) and somewhat hispid plants of $S$. pontica occur in the Black Sea area, quite often in the same populations. Because of that Tzvelev (1993: 82) reserved the name $S$. pontica var. pontica for hispid plants and proposed var. glabra Tzvelev for glabrous forms of that species, which are more common, at least along northern shores of the Black Sea.

Thus, the diagnostic characters given for $K$. dodecanesicum by Brullo et al. (2015b) seem to be rather elusive and/or variable. However, the rather short, inflated and prominently succulent bracts/ bracteoles abruptly contracted into thin and quite long spines reported for $K$. dodecanesicum and illustrated in Brullo et al. (2015b: 62, Fig. 1; 64, Fig. 3) are normally not peculiar to specimens of $S$. pontica from northern shores of the Black Sea. The reported morphological differences between the mainly Pontic (also occurring in some localities in the Eastern Mediterranean area) and the eastern Mediterranean races are better suited for subspecies rather than two separate species.

But is Kali dodecanesicum really a new species?

At the end of his treatment of Salsola in De Candolle's Prodromus, Moquin-Tandon (1849: 190) provided a list (with descriptions and other data) of some insufficiently known species ("Species non satis notae"), which he, although, accepted. One of such species was Salsola squarrosa Steven ex Moq., for which the following information was given:

"40. S. sQuarrosa (Stev. obs. ined. in herb. Willd. 1840), foliis teretiusculis oblongis mucronatis... - In ins. Naxo. Folia carnosa, reflexa. Flores axillares. - An S. Kali varietas?"

As we see, the species was known to Moquin-Tandon by only one collection in the Willdenow herbarium in Berlin (B), which was annotated by Ch. Steven. A short diagnostic description has been published as well, so 
there is no doubt that the name $S$. squarrosa is valid. The plant was collected in the island of Naxos (Greece).

There is just one specimen in B (B-Willd, Willdenow Herbarium) matching the protologue of $S$. squarrosa (B-W-05383010, digital images available from http:// herbarium.bgbm.org/object/BW05383010 [image ID: 325010] and http://plants.jstor.org/stable/10.5555/ al.ap.specimen.b\%20-w\%2005383\%20-01\%200). The text on the Willdenow Herbarium folder follows: "Pentandria Digynia / Salsola squarrosa / foliis teretiusculis oblongis / carnosis mucronatis reflexis / floribus axillaribus / Habitat in insula Naxos". As we see, that text closely matches the published description (Moquin-Tandon, 1849: 190). The herbarium sheet bears two labels: [Label 1] "Salsola Kali L. var.! (v. Pounge)" and [Label 2] "In insula Naxia (Schwartz)". There are also the following texts written directly on the sheet: "S. squarrosa. S." (top right corner) and "Schwartz Centuria. W." (bottom right corner). The plant fragment is ca. $17 \mathrm{~cm}$ long; the plant is yellowish-green, slightly hispid or papillose; flowers/fruits condensed; bracts and bracteoles short (probably prominently succulent and inflated when fresh), abruptly contracted into long subulate spines.

Judging from the high-resolution digital image of the type (holotype) specimen, the brief original description (Moquin-Tandon, 1849: 190), and other available evidence (including the obvious geographic proximity of loci classici), there should be no doubt that Salsola squarrosa is the priority name for the taxon described later as Kali dodecanesicum (Brullo et al., 2015b).

Moreover, $S$. squarrosa seems to be the earliest available binomial applicable for the whole Mediterranean coastal complex of races known earlier as $S$. pontica, $S$. controversa, and under the misapplied names $S$. tragus auct. and Kali macrophylla sensu Galasso \& Bartolucci (2014: 83; non S. macrophylla R. Br.). Consequently, if just one native coastal species of Salsola is recognized in the Pontic-Mediterranean area, it should be called $S$. squarrosa (sensu lato). However, before proposing a nomenclatural and taxonomic solution, it is necessary to consider another name applicable to Mediterranean plants, $S$. controversa.

\section{What is Salsola controversa Tod. ex Lojac.?}

In my recent article (Mosyakin, 2017: 410) I commented that the coastal species of Salsola from the Black Sea area (which I accepted as S. pontica) "belongs to a problematic group of Pontic-Mediterranean coastal taxa currently known as $S$. pontica (either sensu lato or sensu stricto) and Kali dodecanesicum C. Brullo, Brullo, Giusso \& Ilardi (see Brullo et al. 2015b). No nomenclatural combination in Salsola is currently available for the latter taxon; however, it is quite possible that it is in fact conspecific with $S$. controversa Tod. ex Lojac. described from Sicily (Lojacono Pojero, 1904: 271-272), which in that case will be the correct name for this Mediterranean species (if it is indeed specifically distinct from $S$. pontica), or for the whole PonticMediterranean coastal group (if treated as one species, incl. S. pontica)". I also indicated that $S$. controversa was validated by Lojacono Pojero (1904: 271-272), not by Nyman (see also Rilke, 1999; Domina et al., 2014). This species was firmly forgotten even by Italian authors (probably because its name was considered invalid), and only occasionally $S$. controversa was mentioned in literature, mainly as a synonym of $S$. kali or $S$. tragus (see, e.g., Casu, 1910). It has not been mentioned at all in recent Italian publication on Salsola sensu lato (Brullo et al., 2013, 2015a, b) and in the inventory of plant species described from Italy and their loci classici (Peruzzi et al., 2015).

Formally, all herbarium specimens distributed by Todaro under No. 1088 (now present in many herbaria) are syntypes of $S$. controversa. However, my analysis of high-resolution images of various specimens available online (in particular, K000899539, K000899540, P05157673, P05344327, etc., most of them available from JSTOR Global Plants: https://plants.jstor.org; and especially specimens from PAL, see below) indicate that Todaro's plants deposited in various collections are rather diverse morphologically. They in fact represent either a mixed collection or several gatherings, and belong to three entities: (1) the coastal taxon ( $S$. controversa sensu stricto), (2) S. tragus, and (3) forms morphologically intermediate between these taxa. Because of that, proper typification of $S$. controversa becomes a crucial issue, especially if we intend to preserve the original application of the name established by its validating author, Lojacono Pojero (1904).

Sukhorukov (2014: 332) listed in synonymy of Kali pontica the name "Salsola controversa Todaro ex Nym., Consp. Fl. Eur. 3: 631 (1881)" and designated its lectotype, with the following citation: "Lectotypus (Sukhorukov, designated here): Palermo, in arenosis maritimis, IX. [sensu anno], Todaro 1088 (K-000899539!, iso - K-000899540 !)" (here "sensu anno" is evidently an error, probably meaning "sine anno", "no year indicated"). In my opinion, this lectotype designation was a premature decision, because of the considerations that follow. First, Sukhorukov probably has not seen the real protologue and original description of S. controversa, because Flora Sicula (Lojacono Pojero, 1904) is not cited anywhere in his book (Sukhorukov, 2014), while no description of the species was provided by Nyman, who simply cited the name $S$. controversa 
in synonymy. Second, the sheet K000899539 (image available from: https://plants.jstor.org/stable/10.5555/ al.ap.specimen.k000899539) evidently contains two morphologically different plant fragments: the lefthand plant is pale green to yellowish green (probably the living plant was light green to yellowish green) while the right-hand fragment is dark green. The left-hand plant has better developed (more mature) fruits than the right-hand one, which is only flowering. Both plant fragments have rather lax inflorescences, with flowers/ fruits not much condensed on branches.

Lojacono Pojero (1904: 272) in his detailed original description reported that his species is glaucous-green ("...glaucescens..."), with flowers arranged in very dense and large panicle-like inflorescences ("...floribus densissimis secus ramulos alternos paniculatos crebris magnis fere contiguis..."), and with strongly angular branches ("...ramis <...> omnibus valide angulatis..."). Thus, morphological characters of the pale green fragment (left-hand plant, K000899539) are evidently in conflict with the protologue. The taxonomic identity of the right-hand (immature) fragment is problematic, especially if we take into consideration that the specimens distributed by Todaro under No. 1088 represent a mixed collection or several gatherings of rather diverse plants belonging to two or three entities (see above). However, the right-hand fragment is morphologically very similar to plant fragments mounted on the sheet K000899540 (reported as an isolectotype by Sukhorukov, 2014). Plant fragments on K000899540 (image available from https://plants.jstor.org/stable/10.5555/al.ap.specimen. k000899540) have tepals with rather well developed wings and, in my opinion, definitely belong to $S$. tragus (as well as P05157673: https://science.mnhn.fr/ institution/mnhn/collection/p/item/p05157673; and some other specimens of Todaro No. 1088). Characters of the right-hand fragment of K000899539 also contradict the protologue; in particular, in the shape of inflorescences (terminal branches with flowers/fruits are not particularly dense and not "paniculate"); the plant seems to be very sparsely short-papillose, while Lojacono Pojero reported his species as glabrous.

The specimen K000899539 has an additional label (in the lower right corner of the sheet) "Herbarium Kewense. Herbarium Churchillanum Proprium. Bequeathed, 1906" indicating that it was added to the Kew herbarium in 1906, after the death of G.C. Churchill. He was donating parts of his private collection to K starting from 1884, and in 1892 "in connection with a will he thought of making, he announced the intention he had formed of bequeathing to Kew his European herbarium" (Hemsley, 1906: 386). The main European part of his private herbarium was accumulated for many years, but already in 1899 Churchill was unable to add specimens to his collection because of his failing health (see relevant details in Hemsley, 1906). Thus, it is evident that Lojacono Pojero has never seen the specimen K000899539 (the lectotype designated by Sukhorukov, 2014) and did not use it when he was preparing the validating description of $S$. controversa in Flora Sicula. In contrast, Lojacono Pojero evidently used the collections of the Herbarium Siculum in Palermo (now Herbarium Mediterraneaum Panormitanum, PAL) until 1913, when he left Palermo (Domina et al., 2014).

In view of the new information about patterns of diversity of coastal Mediterranean taxa and the need for precise application of the name $S$. controversa, there are two possible ways of coping with the uncertain situation caused by Sukhorukov's lectotypification. The first option is to accept his lectotypification, despite its conflict with the protologue; in that case, a second-step lectotypification (right-hand immature fragment?) with simultaneous epitypification is be needed. However, in my opinion, both plants on the sheet K000899539 do not match the protologue in many of their morphological characters: the plant fragments are not glaucous, their flowers/fruits are not condensed on the branches and not arranged in very dense and large panicle-like inflorescences, and branches are not strongly angular. At least one (right-side) plant fragment most probably belongs to $S$. tragus. Thus, the only reasonable option under Art. 9.19 of ICN (McNeill et al., 2012) is to have that lectotypification (Sukhorukov, 2014) superseded because of its evident and serious enough conflict with the protologue (Art. 9.19(b) of ICN: McNeill et al., 2012) and to select another lectotype among several specimens from PAL, which perfectly match the original detailed description provided by Lojacono Pojero (1904).

There are four Todaro's specimens in PAL available online and identified as $S$. controversa, all with printed labels (No. 1088). A PAL specimen on sheet with ID No. 58916 (image available from: http://147.163.105.223/herbarium_vdetails_en2. asp?idmode $=$ simple $\&$ id $=71449$ ) is immature; the plant has narrow, almost filiform leaves and most probably belongs to $S$. tragus sensu stricto. Morphological characters of plant fragments of three specimens correspond to the characters given in the protologue. The specimen with PAL ID No. 58918 (http://147.163.105.223/herbarium_vdetails_en2. asp? $\mathrm{idmode}=$ simple $\& \mathrm{id}=71451)$ is designated here as the lectotype of $S$. controversa (see below). Two other specimens (PAL ID Nos. 58915 and 58917; see links to images below) are considered isolectotypes. 


\section{A taxonomic and nomenclatural solution for Pontic- Mediterranean coastal taxa of Salsola}

Unfortunately, Brullo et al. (2013, 2015a, b) and almost all other authors who recently commented on taxonomy of Pontic-Mediterranean taxa of Salsola (e. g., Sukhorukov, 2014) did not mention an interesting article on phylogeography of some European coastal plants (Kadereit et al., 2005), partly based on results from the dissertation by Arafeh (2005). That article provided noteworthy data and conclusions on the genetic and geographical differentiation of five coastal species, including the taxon listed under the name Salsola kali. Their molecular phylogeography results based on AFLP evidence clearly indicate that three rather distinct but closely related lineages of coastal Salsola exist in the Pontic-Mediterranean area. Unfortunately, Kadereit et al. (2005) refrained from discussing taxonomy of the taxa involved and made no attempt to match the revealed lineages with any existing names in Salsola.

The studied taxon (in fact, taxa) was accepted as $S$. kali sensu latissimo, including at least five entities corresponding, in my opinion, to $S$. kali sensu stricto (Atlantic and Baltic race), S. tragus (inland weedy race), $S$. controversa (western Mediterranean), S. squarrosa (= Kali dodecanesicum; eastern Mediterranean), and $S$. pontica sensu stricto (mainly Pontic, with extensions to the eastern Mediterranean area). Following these molecular results and the taxonomic discussion provided above, one may prefer to accept $S$. controversa, $S$. squarrosa, and $S$. pontica as separate species. However, considering the evident genetic similarity (Kadereit et al., 2005) and blurred morphological and geographical borders of these three coastal taxa, I prefer to treat them as three subspecies of $S$. squarrosa (see new combinations below).

Further detailed morphological, molecular phylogenetic, and phylogeographic studies of coastal Eurasian and all Australasian species of Salsola are needed, preferably in comparison with data on morphologically diverse $S$. tragus and some other Eurasian inland taxa. Reliable morphological characters of the discussed taxa should be further specified using a wider geographical coverage and the population-based approach. It should be also taken into consideration that plants of $S$. tragus quite often co-occur with $S$. squarrosa sensu lato in maritime coastal habitats (at least in the Black Sea area, but probably also in the Mediterranean region: see comments above, under $S$. controversa), where they often develop rather thick and fleshy leaves, and can be thus confused with the coastal taxa.

\section{Nomenclature and new combinations}

I recognize here three subspecies of coastal PonticMediterranean taxa known in recent publications under many properly applied and misapplied names, such as Salsola pontica, S. kali subsp. pontica, S. tragus subsp. pontica, Kali ponticum, K. dodecanesicum, S. tragus auct., p.p., excl. pl. etc. (see Iljin, 1936, 1952; Tzvelev, 1993, 1996; Mosyakin, 1996, 2003; Rilke, 1999; Sukhorukov, Akopian, 2013; Sukhorukov, 2014; Brullo et al., 2013, 2015a, b, and references therein).

Salsola squarrosa Steven ex Moq. in DC., Prodr. 13(2): 190. 1849. (Moquin-Tandon, 1849: 190).

Type (holotype, the only specimen cited in the protologue): [Greece, Naxos] "in ins. Naxo"; Herb. Willd. 5383 (B-W-05383010, images available from http://herbarium.bgbm.org/object/BW05383010 [image ID: 325010] and http://plants.jstor.org/stable/10.5555/ al.ap.specimen.b\%20-w\%2005383\%20-01\%200).

\section{Salsola squarrosa subsp. squarrosa}

Type: see above.

$=$ Kali dodecanesicum C. Brullo, Brullo, Giusso \& Ilardi, Phytotaxa 218(1): 63. 2015. (Brullo et al., 2015b: 63).

Type (holotype): "GREECE. Dodecanese: Rhodes,

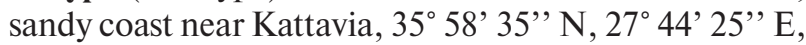
22 August 2013, S. Brullo \& V. Ilardi s.n." (CAT).

Salsola squarrosa subsp. controversa (Tod. ex Lojac.) Mosyakin, comb. nov.

Basionym: Salsola controversa Tod. ex Lojac., Fl. Sicula 2(2): 271. 1904. (Lojacono Pojero, 1904: 271, description on page 272).

Type(lectotype, designated here): "Todaro. Flora Sicula Exsiccata. Salsola controversa Tod. enum. fl. sic. ined. In arenosis maritimis-Palermo. Septembri. n. 1088. Legit Todaro" (PAL ID No. 58918, image available from http://147.163.105.223/herbarium_vdetails_en2. asp? idmode $=$ simple $\& i d=71451)$. Isolectotypes: PAL ID No. 58915 (http://147.163.105.223/herbarium_vdetails en2.asp?idmode $=$ simple\&id $=71448) ;$ PAL ID No. 58917 (http://147.163.105.223/herbarium_vdetails_en2. asp?idmode $=$ simple $\&$ id $=71450) ;$ P05344327 (https:// science.mnhn.fr/institution/mnhn/collection/p/item/ p05344327).

The earlier lectotypification (Sukhorukov, 2014: 332) is superseded following Art. 9.19(b) of ICN (McNeill et al., 2012).

Salsola squarrosa subsp. pontica (Pall.) Mosyakin, comb. nov.

Basionym: Salsola kali L. var. pontica Pall., Ill. Pl.: 37. 1803. (Pallas, 1803: 37). 
Type (lectotype, designated by Rilke, 1999: 133): [Ukraine, Crimea, Sudak] "Sudagh. Herb. Pallas" (BM000016635, image available from: https:// plants.jstor.org/stable/10.5555/al.ap.specimen. bm000016635).

$\equiv$ Salsola ruthenica Iljin subsp. pontica (Pall.) Iljin, Sorn. rast. SSSR [Сорные растения СССР] 2: 140. 1934. $\equiv$ S. pontica (Pall.) Iljin, Fl. URSS [Флора CССР] 6: 212. 1936, nom. inval. $\equiv S$. pontica (Pall.) Degen, Fl. Velebit. 2: 47. 1937. $\equiv S$. kali L. subsp. pontica (Pall.) Mosyakin, Ann. Missouri Bot. Gard. 83: 389. 1996. $\equiv$ S. tragus L. subsp. pontica (Pall.) Rilke, Biblioth. Bot. 149: 133. 1999. EKali ponticum (Pall.) Sukhor., Novosti Sist. Vyssh. Rast. [Новости систематики высших растений] 42: 106. 2011, as "pontica". $\equiv$ Kali tragus (L.) Scop. subsp. ponticum (Pall.) Mosyakin, Ukrayins'k. Bot. Zhurn. [Український ботанічний журнал] 69(3): 395. 2012, as "pontica".

\section{Acknowledgments}

I am grateful to Prof. Helmut Freitag (University of Kassel, Germany), Dr. Ahmet Emre Yaprak (Ankara University, Turkey), and Dr. Leila M. Shultz (Utah State University, Logan, Utah, USA), with whom I discussed some issues of taxonomy and nomenclature of Salsola sensu lato. Thanks are due to an anonymous reviewer for his/her comments on the manuscript. Victoria McMichael and Mary Stiffler (Peter H. Raven Library, Missouri Botanical Garden, St. Louis, Missouri, USA) provided copies of some rare publications, and their kind help is gratefully acknowledged. Herbarium assistance of Dr. Natalia M. Shiyan (Head Curator, National Herbarium of Ukraine - KW, M.G. Kholodny Institute of Botany of the National Academy of Sciences of Ukraine) and Alisa V. Shumilova (Curatorial Assistant, $K W$ ) is greatly appreciated.

\section{REFERENCES}

Akhani H., Edwards G., Roalson E.H. Diversification of the Old World Salsoleae s. 1. (Chenopodiaceae): molecular phylogenetic analysis of nuclear and chloroplast data sets and a revised classification. Int. J. Plant Sci., 2007, 168(6): 931-956. http://dx.doi.org/10.1086/518263

Akhani H., Greuter W., Roalson E.H. Notes on the typification and nomenclature of Salsola and Kali (Chenopodiaceae). Taxon, 2014, 63(3): 647-650. https://doi.org/10.12705/633.1

Arafeh R.M. Molecular phylogeography of the European coastal plants Crithmum maritimum L., Halimione portulacoides (L.) Aellen, Salsola kali L. and Calystegia soldanella (L.) R. Br. [Dissertation zur Erlangung des Grades "Doktor der Naturwissenschaften". Am
Fachbereich Biologie der Johannes GutenbergUniversität in Mainz], Mainz, 2005, 84 pp.

Ayres D., Ryan F.J., Grotkoo E., Bailey J., Gaskin J. Tumbleweed (Salsola section Kali) species and speciation in California. Biol. Invasions, 2009, 1: 1175-1187.

Backer C.A. Chenopodiaceae. In: Flora Malesiana, series 1: Spermatophyta. Ed. C.G.G.J. van Steenis. Batavia: Noordhoff-Kolff N.V., 1949, vol. 4(2), pp. 99-106.

Bentham G. Chenopodiaceae. In: Flora Australiensis: a description of the plants of the Australian territory. London: Reeve and Co., 1870, vol. 5, pp. 150-208.

Boerlage J.G. Handleiding tot de kennis der flora van Nederlandsch Indië. Beschrijving van de families en geslachten der Nederl. Indische phanerogamen. Leiden: E.J. Brill, 1900, vol. 3(1), xxxi + 418 pp.

Borger C.P.D., Yan G., Scott J.R., Walsh M., Powles S.B. Salsola tragus or $S$. australis (Chenopodiaceae) in Australia - Untangling the taxonomic confusion through random amplified microsatellite polymorphism (RAMP) and cytological analysis. Austral. J. Bot., 2008, 56: 600608. http://dx.doi.org/10.1071/BT08043

Botschantzev V.P. A synopsis of Salsola (Chenopodiaceae) from South and South-West Africa. Kew Bull., 1974, 29: 597-614. http://dx.doi.org/10.2307/4108004

Brullo C., Brullo S., Giusso del Galdo G., Guarino R., Iamonico D. Il genere Salsola s. 1. (Chenopodiaceae) in Italia. In: Contributi alla ricerca floristica in Italia. Eds S. Peccenini, G. Domina. Firenze: Soc. Bot. Italiana, 2013, pp. 35-38.

Brullo C., Brullo S., Gaskin J.F., Giusso del Galdo G., Hrusa G.F., Salmeri C. A new species of Kali (Salsoloideae, Chenopodiaceae) from Sicily, supported by molecular analysis. Phytotaxa, 2015a, 201(4): 256-277. http://dx.doi.org/10.11646/phytotaxa.201.4.2

Brullo C., Brullo S., Ilardi V., Giusso del Galdo G. Kali dodecanesicum (Chenopodiaceae, Salsoloideae) a new species from Greece. Phytotaxa, 2015b, 218(1): 61-68. http://dx.doi.org/10.11646/phytotaxa.218.1.4

Casu A. Salsola Kali L. e Salsola Tragus L.: Specie critiche. Memorie della Reale Accademia delle Scienze di Torino, Ser. 2, 1910, 60: 393-407.

Chinnock R.J. Some observations on Salsola L. (Chenopodiaceae) in Australia. J. Adelaide Bot. Gard., 2010, 24: 75-79.

Domina G., Greuter W., Mazzola P., Raimondo F.M. Names of Italian vascular plants published by Michele Lojacono Pojero. Fl. Medit. 2014, 24: 215-232. http:// dx.doi.org/10.7320/FlMedit24.215

Fourreau M. Catalogue des plantes du cours du Rhone (suite et fin). Annales de la Société Linnéenne de Lyon (nouvelle série), 1869, 17: 89-200.

Galasso G., Bartolucci F. Notula: 2070 (Kali macrophyllum, comb. nov.) / Notulae alla checklist della flora vascolare italiana: 17 (2027-2070). Inform. Bot. Ital., 2014, 46(1): 83.

Hemsley W.B. [under initials "W. B. H."; an untitled note about G.C. Churchill in:] Miscellaneous notes. LIV [No. 54]. Bull. of Miscellaneous Information (Royal Botanic Gardens, Kew), 1906, [Vol. of 1906] No. 9: 384-392. 
Hernández-Ledesma P., Berendsohn W.G., Borsch T., von Mering S., Akhani H., Arias S., Castañeda-Noa I., Eggli U., Eriksson R., Flores-Olvera H., FuentesBazán S., Kadereit G., Klak C., Korotkova N., Nyffeler R., Ocampo G., Ochoterena H., Oxelman B., Rabeler R.K., Sanchez A., Schlumpberger B.O., Uotila P. A taxonomic backbone for the global synthesis of species diversity in the angiosperm order Caryophyllales. Willdenowia, 2015, 45: 281-383. http://dx.doi.org/10.3372/wi.45.45301

Hooker J.D. On the flora of Australia: its origin, affinities, and distribution: being an introductory essay to the Flora of Tasmania. London: Lovell Reeve, 1859, vii + cxxviiii pp.

Hooker W.J. Belanger's travels. Companion to the Botanical Magazine, "1835" (publ. 1836), 1: 285-288.

Hrusa G.F., Gaskin J.F. The Salsola tragus complex in California (Chenopodiaceae): characterization and status of Salsola australis and the autochthonous alllopolyploid Salsola ryanii sp. nov. Madroño, 2008, 55(2): 113-131. http://dx.doi.org/10.3120/0024-9637(2008)55[113:TST CIC]2.0.CO;2

Iljin M.M. Chenopodiaceae. In: Flora USSR, Ed. V.L. Komarov. Moscow; Leningrad: Acad. Sci. USSR Publ., 1936, vol. 6, pp. 2-354. [Ильин M.M. Chenopodiaceae. В кн.: Флора СССР. Ред. В.Л. Комаров, М.; Л.: Изд-во АН СССР, 1936, т. 6, с. 2-354].

Iljin M.M. Chenopodiaceae. In: Flora URSR. Ed. M.I. Kotov. Kyiv: Acad. Sci. Ukr. RSR Publ., 1952, vol. 4, pp. 267313, 650. [Ільїн М.М. Chenopodiaceae. В кн.: Флора Української РСР. Ред. М.І. Котов. Київ: Вид-во АН УРСР, 1952, т. 4, с. 267-313, 650].

Kadereit J.W., Arafeh R., Somogyi G., Westberg E. Terrestrial growth and marine dispersal? Comparative phylogeography of five coastal plant species at a European scale. Taxon, 2005, 54(4): 861-876.

Lojacono Pojero M. Flora Sicula o Descrizione delle piante vascolare spontanee o indigenate in Sicilia. Palermo: TipoLitografia Salvatore Bizzarrilli, 1904, vol. 2(2), 428 p. + 20 tab.

Miquel F.A.W. Flora van Nederlandsch Indie [alternative Latin title: Flora Indiae Batavae]. Amsterdam: C.G. van der Post \& Utrecht: C. van der Post Jr. \& Leipzig: Fried. Fleischer, 1855, vol. 1(1), xxiv + 1116 pp. + XIV tab.

Moquin-Tandon A. Conspectus generum Chenopodearum (Atriplicearum Juss. et Chenopodearum DC. Gen.). Ann. Sci. Natur., Sér. 2, 1835, vol. 4 (Botanique): 209-218.

Moquin-Tandon A. Chenopodearum monographica enumeratio. Parisiis [Paris]: Sumptibus Victoris Masson, 1840, ix $+182 \mathrm{pp}$.

Moquin-Tandon A. Ordo Salsolaceae. In: A. De Candolle. Prodromus Systematis Naturalis Regni Vegetabilis. Parisiis [Paris]: Apud P.-J. Loss, Bibliopolam, 1849, vol. 13(2), pp. 41-219.

Mosyakin S.L. A taxonomic synopsis of the genus Salsola L. (Chenopodiaceae) in North America. Ann. Missouri Bot. Gard., 1996, 83: 387-395. http://dx.doi.org/10.2307/2399867

Mosyakin S.L. Salsola. In: Flora of North America north of Mexico. Ed. by Flora of North America Editorial Committee, New York; Oxford: Oxford Univ. Press, 2003, vol. 4, pp. 398-403.
Mosyakin S.L. The first record of Salsola paulsenii (Chenopodiaceae) in Ukraine, with taxonomic and nomenclatural comments on related taxa. Ukr. Bot. J., 2017, 74(5): 409-420, available at: https://doi.org/10.15407/ukrbotj74.05.409

Mosyakin S.L., Freitag H., Rilke S. Kali versus Salsola: the instructive story of a questionable nomenclatural resurrection. Israel J. Pl. Sci., 2017, 64: 18-30. http://dx.doi.org/10.1080/07929978.2016.1256135

Mosyakin S.L., Rilke S., Freitag H. Proposal to conserve the name Salsola (Chenopodiaceae s. str.; Amaranthaceae sensu APG) with a conserved type. Taxon, 2014, 63: 1134-1135. https://doi.org/10.12705/635.15

Mueller F., von. Iconography of Australian salsolaceous plants, 9 [ninth decade]. Melbourne: Robert S. Brain, Govern. Printer, 1891, tab. LXXXI-XC.

Pallas P.S. Illustrationes plantarum imperfecte vel nondum cognitarum, cum centuria iconum. De Halophytis, seu plantis apetalis kalicis generatim. Lipsiae [Leipzig]: Sumtibus Godofredi Martini, 1803, 68 pp. + LIX tab.

Peruzzi L., Domina G., Bartolucci F. et al. [35 authors]. An inventory of the names of vascular plants endemic to Italy, their loci classici and types. Phytotaxa, 2015, 196(1): 1-217.

Rilke S. Revision der Sektion Salsola s. 1. der Gattung Salsola (Chenopodiaceae). Bibliotheca Botanica, 1999, 149: 1-190.

Ross R. The botany of Belanger's voyage. Taxon, 1964, 13(6): 193-196.

Schüssler C., Freitag H., Koteyeva N., Schmidt D., Edwards G., Voznesenskaya E., Kadereit G. Molecular phylogeny and forms of photosynthesis in tribe Salsoleae (Chenopodiaceae). J. Experim. Bot., 2017, 68(2): 207-223.

Sukhorukov A.P. The carpology of the family Chenopodiaceae in relations to problems of phylogeny, systematics and diagnostics of its representatives. Tula: Grif i K, 2014, 400 pp. [Сухоруков А.П. Карпология семейства Chenopodiaceae в связи с проблемами филогении, систематики и диагностики его представителей, Тула: Гриф и К., 2014, 400 с.].

Sukhorukov A.P., Akopian J.A. A compendium of the Chenopodiaceae in the Caucasus. Moscow: MAKS Press, 2013, 76 рр. [Сухоруков А.П., Акопян Ж.А. Конспект семейства Chenopodiaceae Кавказа, М.: МАКС Преcc, 2013, 76 c.].

Thiers B. Index Herbariorum. A global directory of public herbaria and associated staff. New York Botanical Garden's Virtual Herbarium. 2017-onward, available at: http://sweetgum.nybg.org/science/ih (Accessed November 2017).

Tzvelev N.N. Notes on Chenopodiaceae of Eastern Europe. Ukr. Bot. J., 1993, 50(1): 78-85. [Цвелев Н.Н. Заметки о маревых Восточной Европы. Укр. бот. журн., 1993, 50(1): 78-85].

Tzvelev N.N. Tribe Salsoleae. In: Flora Europae Orientalis. Ed. N.N. Tzvelev. St. Petersburg: Mir i Semya-95, 1996, vol. 9, pp. 74-92. [Цвелев Н.Н. Триба Salsoleae. В кн.: Флора Восточной Европы. Ред. Н.Н. Цвелев, СПб: Мир и Семья-95, 1996, т. 9, с. 74-92].

Voznesenskaya E.V., Koteyeva N.K., Akhani H., Roalson E.H., Edwards G.E. Structural and physiological analyses in Salsoleae (Chenopodiaceae) indicate multiple transitions among $\mathrm{C}_{3}$, intermediate, and $\mathrm{C}_{4}$ 
photosynthesis. J. Experim. Bot., 2013, 64: 3583-3604. http://dx.doi.org/10.1093/jxb/ert191

Walter T. Flora Caroliniana. London, 1788. 263 pp.

Ward D.B. Thomas Walter Typification Project, I: Observations on the John Fraser folio. Sida, 2006, 22: 1111-1118.

Ward D.B. The Thomas Walter Herbarium is not the herbarium of Thomas Walter. Taxon, 2007, 56(3): 917-926.

Ward D.B. Thomas Walter Typification Project, V: Neotypes and epitypes for 63 Walter names, of genera D through $\mathrm{Z}$. J. Bot. Res. Inst. Texas, 2008, 2: 475-486.

Wen Zh.-B., Zhang M.-L., Zhu G.-L., Sanderson S.C. Phylogeny of Salsoleae s. 1. (Chenopodiaceae) based on DNA sequence data from ITS, $p s b \mathrm{~B}-p s b \mathrm{H}$, and $r b c \mathrm{~L}$, with emphasis on taxa of northwestern China. Pl. Syst. Evol., 2010, 288: 25-42. http://dx.doi.org/10.1007/s00606-010-0310-5

Wen Z.B., Zhang M.L. Anatomical types of leaves and assimilating shoots and carbon ${ }^{13} \mathrm{C} /{ }^{12} \mathrm{C}$ isotope fractionation in Chinese representatives of Salsoleae s. 1. (Chenopodiaceae). Flora - Morphology, Distribution, Functional Ecology of Plants, 2011, 206(8): 720-730. https://doi.org/10.1016/j.flora.2010.11.015

Wilson P.G. Chenopodiaceae. In: Flora of Australia. Ed. A.S. George. Canberra: Austral. Government Publ. Service, 1984, vol. 4, pp. 81-317.

Recommended for publication by

Submitted 10.11.2017

Zigmantas Gudžinskas

Мосякін С.Л. Таксономічні та номенклатурні нотатки про понтично-середземноморські та деякі австралазійські таксони Salsola (Chenopodiaceae). Укр. бот. журн., 2017, 74(6): 521-531.

Інститут ботаніки ім. М.Г. Холодного НАН України вул. Терещенківська, 2, Київ 01004, Україна

Проаналізовано сучасні та історичні погляди щодо систематики та номенклатури понтично-середземноморських та деяких австралазійських таксонів Salsola (Chenopodiaceae). Обговорюється таксономія та номенклатура декількох назв, які раніше застосовувалися до представників видової групи, що здебільшого була визнана у недавніх публікаціях під назвою Salsola pontica (Pall.) Degen s. 1. Показано, що Kali dodecanesicum C. Brullo \& al. $€$ синонімом раніше описаного виду Salsola squarrosa Steven ex Moq.; остання назва є пріоритетною у ранзі виду для усієї понтично-середземноморської групи таксонів. Ця група представлена західносередземноморською (S. controversa Tod. ex Lojac.), східносередземноморською ( $S$. squarrosa s. str.) та переважно чорноморсько-каспійською (S. pontica s. str.) географічними расами. Враховуючи нечіткі морфологічні та географічні межі між цими таксонами, їх доцільно розглядати як три підвиди виду S. squarrosa: subsp. controversa (Tod. ex Lojac.) Mosyakin, comb. nov., subsp. squarrosa, та subsp. pontica (Pall.) Mosyakin, comb. nov., відповідно. Показано, що вид S. macrophylla $\mathrm{R}$. Br. (описаний з Австралії) є відмінним від усіх понтично-середземноморських прибережних таксонів; натомість він, очевидно, споріднений з нині визнаним видом $S$. australis R. Вr. Ідентичність $S$. brachypteris Moq. (описаний з о. Ява, Індонезія) лишається невизначеною; судячи з наявних даних, цей таксон, ймовірно, споріднений з S. macrophylla або з деякими іншими недостатньо відомими австралазійськими видами. Стисло розглянута проблема типіфікації та застосування назви S. caroliniana Walter; зроблено висновок, що цю назву слід запропонувати до відхилення. Наголошено на потребі проведення подальших морфологічних, молекулярно-філогенетичних та філогеографічних досліджень приморських євразійських та австралазійських видів Salsola.

Ключові слова: Salsola, Chenopodiaceae, Salsoloideae, номенклатура, систематика, біогеографія

Мосякин С.Л. Таксономические и номенклатурные заметки о понтическо-средиземноморских и некоторых австралазийских таксонах Salsola (Chenopodiaceae). Укр. бот. журн., 2017, 74(6): 521-531.

Институт ботаники им. Н.Г. Холодного НАН Украины ул. Терещенковская, 2, Киев 01004, Украина

Проанализированы современные и исторические взгляды на систематику и номенклатуру понтическо-средиземноморских и некоторых австралазийських таксонов рода Salsola (Chenopodiaceae). Обсуждены систематика и номенклатура нескольких названий, которые ранее применялись к представителям видовой группы, которая признавалась в недавних публикациях преимущественно под названием Salsola pontica (Pall.) Degen s. 1. Показано, что Kali dodecanesicum C. Brullo \& al. является синонимом ранее описанного вида Salsola squarrosa Steven ex Moq.; последнее название является приоритетным в ранге вида для всей понтическо-средиземноморской группы таксонов. Эта группа представлена западносредиземноморской ( $S$. controversa Tod. ex Lojac.), восточносредиземноморской ( $S$. squarrosa s. str.) и преимущественно черноморско-каспийской ( $S$. pontica s. str.) географическими расами. Учитывая нечеткие морфологические и географические границы между этими таксонами, их целесообразно рассматривать как три подвида вида $S$. squarrosa: subsp. controversa (Tod. ex Lojac.) Моsyakin, comb. nov., subsp. squarrosa, и subsp. pontica (Pall.) Mosyakin, comb. nov., соответственно. Показано, что вид S. macrophylla R. Br. (описан из Австралии) отличается от всех понтическо-средиземноморских прибрежных таксонов; он, очевидно, является родственным признанному сейчас виду $S$. australis $\mathrm{R}$. Вr. Идентичность S. brachypteris Moq. (описан с о. Ява, Индонезия) остается неопределенной; судя по имеющимся данным, этот таксон, вероятно, родственен $S$. macrophylla или некоторым другим недостаточно изученным австралазийским видам. Кратко рассмотрена проблема типификации и применения названия S. caroliniana Walter; сделан вывод о том, что это название следует предложить номенклатурно отвергнуть. Отмечена необходимость проведения дальнейших морфологических, молекулярно-филогенетических и филогеографичних исследований приморских евразийских и австралазийских видов Salsola.

Ключевые слова: Salsola, Chenopodiaceae, Salsoloideae, номенклатура, систематика, биогеография 